\title{
The Influence of the Technological Parameters of Rolling in the Helical Rollers and Longitu- dinal Wedge Mill on the Quality of Two-Phase Titanium Alloy
}

\begin{abstract}
Aigerim Mashekova, Adilzhan Nurtazaev, Serik Mashekov, Aiman Alshynova, Elmira Tussupkaliyeva Institute of Industrial Engineering, Kazakh National Research Technical University after K.I. Satpayev, 22a, Satpayev street, Almaty, 050013, Republic of Kazakhstan; mashekovaaigerim@mail.ru; adilghan@mail.ru;
\end{abstract} mashekov.1957@mail.ru; aiman16@mail.ru; elatus78@mail.ru.

This article presents a new technology of obtaining the flat products with an ultrafine structure. The ultrafinegrained structure is obtained by using severe plastic deformation which is developed by the helical rollers. The stress-strain state (SSS) of the workpiece during rolling process in the helical rollers and longitudinal wedge mill is investigated in this scientific paper. The quantitative data has been obtained by the finite element method and MSC.SuperForge software; as well as the basic SSS distribution patterns, the temperature in simulating the rolling in the helical rollers and longitudinal wedge mill with different number of passes and the single reduction have been established. The rational technology of rolling the two-phase titanium alloys was developed and tested in the laboratory. The special attention is paid to analysis of the influence of the rolling conditions in the helical rollers and longitudinal wedge mill on the formation of VT6 titanium alloy microstructure.

Keywords: the titanium alloys, the rolling, the stress-strain state, a numerical simulation, a single reduction.

\section{References}

[1] CHEPKIN, V. (1995). The experience and the problems of application of titanium alloys in the aircraft engines. In: Titan, Vol. 1, No. 2, pp. 13-15. IAT. Russia.

[2] SEMENOV, E. (1985). Forging and Stamping, pp. 3 - 568. Mechanical Engineering, Moscow.

[3] MASHEKOV, S., SMAYLOVA, N., MASHEKOVA A. (2013). Problems of forging the titanium alloys and their solutions, pp. 230 - 251. LAP LAMBERT Academic Publishing, Saarbrücken

[4] VALIEV, R., ALEXANDROV, I. (2000). Nanostructured materials subjected to the severe plastic deformation, pp. 3 - 272. Logos, Moscow.

[5] KOLOBOV, YU., VALIEV, R., GRABOVETSKAYA, G. (2001). Grain-boundary diffusion and properties of nanostructured materials, pp. 3 - 232. Science, Novosibirsk.

[6] KAYBYSHEV, O., UTYASHEV, F. (2002). Superplasticity, structure refinement and processing of hard-deformed alloys, pp. 4 -438. Science, Moscow.

[7] SEGAL, V., REZNIKOV, V., KOPYLOV, V. (1994). Processes of plastic structuring of the metal, pp. 4 - 232. Science and technology, Minsk.

[8] BEYGELZIMER, YA., VARYUKHIN, V., ORLOV, D. (2003). The screw extrusion - the process of deformation accumulation, pp. 3 - 86. Firm TEAH, Donetsk.

[9] MAYDANYUK, A., STERN, M., BAGLYUK, G. (2008). Simulation of the equal channel angular pressing of the porous workpieces. In: Improving processes and equipment for forming by pressure in metallurgy and mechanical engineering, pp. 31-36. DDMA, Kramatorsk.

[10] MAYDANYUK, A., RYABICHEVA, L., STERN, M., BAGLYUK, G. (2008). The evolution of the density distribution at an equal channel angular pressing of the porous workpieces. In: Herald of East Ukrainian National University, Vol. 3 (2), pp. 213-216. EUNU. Lugansk.

[11] SYMONOVA, A., DUCOBU, F., WEISS, V. (2016). The mechanics of machining ultrafine-grained grade 2 Ti proceed severe plastic deformation. In: Manufacturing Technology, Vol. 16, No. 3, pp. 627-633.

[12] NOVAKOVA, L., HOMOLA, P., KAFKA, V., (2012). Microstructure analysis of titanium alloys after deformation by means of asymmetric incremental sheet forming. In: Manufacturing Technology, Vol. 12, No. 13, pp. 201-206.

[13] SLOPAKOVA POKOVA, M., CIESLAR, M., ZIMINA, M. (2015). Grain refinement in Al-Mn-Fe-Si alloys by severe plastic deformation. In: Manufacturing Tachnology, Vol. 15, No. 4, pp. 679-684.

[14] VALIEV, R., ALEXANDROV, I. (2007). Bulk nanostructured metal materials, pp. 5 - 398. ECC "Akademkniga", Moscow. 
[15] KRASILNIKOV, N. (2005). The strength and ductility after an equal channel angular pressing with the backward pressure. In: Metals, No. 3, pp. 35-42. ELIZ, Moscow.

[16] EFROS, B., POPOVA, YE., EFROS, N., IVCHENKO, V., VARYUKHIN V. (2005). Influence of the severe plastic deformation on the structure and hardening of polycrystalline nickel. In: Metals, No.6, pp. 31-35. ELIZ, Moscow.

[17] VALIEV, R. (2006). Creation of the nanostructured metals and alloys with the unique properties, using the severe plastic deformation. In: Russian Nanotechnologies, Vol. 1, No. 1 - 2, pp. 208-216. Park-Media. Moscow.

[18] MAREK, I., VOJTECH, D., MICHALCOVA, A., KUBATIC, T.F. (2015). Preparation and mechanical properties of ultra-high-strength nanocrystalline metals. In: Manufacturing Techology, Vol. 15, No. 4, pp. 596 - 684.

[19] TRAINO, A., POLUHIN, V., NIKOLAEV, V. (2011). Intensive macroshift as a non-traditional means of providing the high-quality flat products. In: Metallurg, No. 5, pp 57 - 63. MetallurgIzdat. Moscow.

[20] MASHEKOV, S., ABSADYKOV, B., KURMANGALIYEVA, L., SEKERBEK, A., BIYAKAEVA, N. (2006). The tool for hot-rolling metals and alloys (RK Patent 16804), pp. 2-4. Ministry of Justice of the Republic of Kazakhstan, Astana.

[21] MASHEKOV, S., NUGMAN, E., MASHEKOVA, A. (2009). Continuous mill for rolling strips of steels and alloys (RK Patent 20969), pp. 6-8. Ministry of Justice of the Republic of Kazakhstan, Astana.

[22] KANAVALOV, YU. (2008). The Guidebook of roller. Manufacturing of hot rolled sheets and strips. p. 3 - 640, Thermal technology, Moscow.

[23] SOSNIN, O., IVANOV, YU., GROMOV, V. (2004). Electron microscopic studies of the structural changes in the steel 60GS2 with the fatigue. In: Bulletin of Universities. Ferrous metallurgy, No. 2, pp. 32-34. MISIS, Russian. 